\title{
Nigerian Companies and the Prohibition on Political Donations: A Paradigmatic Shift as a Panacea for Compliance
}

\author{
Dr. Mokutima Ekpo ${ }^{1}$, Dr. Eni Alobo ${ }^{2 *}$ \\ ${ }^{1}$ Senior Lecturer and Head of Public Law, Faculty of Law, University of Calabar - Nigeria. \\ ${ }^{2 *}$ Senior Lecturer, Faculty of Law, University of Calabar - Nigeria And Visiting Scholar, Faculty of Law, University of Port \\ Harcourt-Nigeria.
}

\begin{abstract}
Democratic rule is generally acclaimed as a better form of governance, but its operation does not appear to come cheap. This is especially so in Nigeria where new democratic dispensations are heralded by expensive electioneering campaigns. The funds for these campaigns are sourced from willing donors or through subtle coercion. Corporate organizations are easy prey to politicians. This paper is provoked by the frequency and blatancy with which corporate organizations in Nigeria donate to political parties and for political purposes without any sanctions despite the unambiguous prohibition in S.38 (2) of the Companies and Allied Matters Act (CAMA). This exposes the inability of the provision to halt or reduce this practice to the barest minimum and also reveals the unpopularity of the provision. The paper argued that it is not possible to completely extricate organizations from the political dynamics in their host committees and proffered some mitigating factors which will make the provision more acceptable to the people and more respected. The paper discovered normative reasons why the prohibition in $S .38$ (2) of CAMA is largely ignored.It therefore recommended wide ranging amendments to the provisions so as to enhance compliance, improve its enforcement strategies, reflect present day realities and align it with international best practices.
\end{abstract}

Keywords- Political Finance, Campaign Funding, Political Donations, Company Law, Electoral Act.

\section{INTRODUCTION}

Funding is a critical component of political activities and without money it would be problematic for political parties to propagate their philosophies and agenda to the public and this will make it difficult for the electorates to be well informed and educated as to proper choices during elections. Expectedly, Political activities and campaigns in Nigeria and indeed in some other jurisdictions are usually accompanied by humongous financial expenditure. In Nigeria for instance, campaigns are organised as mini carnivals with enormous fanfare with each party doing it utmost to outdo and out spend the other. This is done with a view to impress the voters as though this could replace ideological discourse. The is sue whether Nigerian political parties are ideologically based is not the focus of this paper, but it is interesting to note the comment by Oji, (2014) that:

Most parties in Nigeria lack ideologies and are not issue oriented, and rather they are manipulated by political entrepreneurs who invest on the parties and expect concurrent returns such investments.

Political party activities and funding in Nigeria are usually associated with contemptible instances of corruption which comes in form of illicit funds, vote buying and manipulations. The devastating and saddening effects of these gifts led Thomas (2016) to rhetorically ask, "who is using their cash to possibly bend the ear of the future President?" It is for this reason that normative and institutional framework have been put in place to regulate political donations by companies thereby placing restrictions and limitations on political funding by corporate entities. Unfortunately and quite regrettably, the effort to regulate political donations and campaign financing is enforced more in breach than compliance. Many laws have been put in place in Nigeria including constitutional fortification on donations to political parties and campaign funding in other to guide and the operations of political parties and restrict their expenditure profile.

The superlative law, the 1999 Constitution of the Federal Republic of Nigeria as amended contains provisions that are designed and constructed to institutionalize probity, accountability and due process in the financial architecture of political parties. Section 225 sub sections 2 of the 1999 Constitution in very unambiguous terms requires and obligates every political party to submit to the Independent National Electoral Commission (INEC) a detailed annual statement and analys is of its sources of funds and other assets together with a similar statement of its expenditure in such form as the commission may 
require. INEC is also given the authority under Subsection 5 of section 225 to give directions to political parties regarding the books or records of financial transactions which they shall keep and, to examine all such books and records.

To further underscore the fundamental character of the provision relating to probity and accountability by political parties and the oversight responsibility of INEC, section 226 (1) provides that the Independent National Electoral Commission, shall in every year prepare and submit to the National Assembly a report on the accounts and balance sheet of every political party. Sub section (2) of the section further provides that:

It shall be the duty of the commission, in preparing its report under this section, to carry out such investigation as will enable it to form an opinion as to whether proper books of account and proper records have been kept by any political party, and if the Commission is of the opinion that proper books of accounts have not been kept by a political party, the Commission shall so report.

Again, the constitution mandates INEC to monitor and scrutinise foreign funding and donations to political parties in Nigeria. In Specific terms, the constitution in section 225 Sub sections 3, prohibits political parties from holding or possessing assets outside Nigeria or be entitled to retain any funds or assets remitted or sent to it from outside. Sub section 4 of the same section states that any funds or other assets remitted or sent to a political party from outside Nigeria shall be paid over or transferred to the commission within twenty-one days of its receipt with such information as the commission may require. It is apparent from the above constitutional provisions that INEC should play a central role in checking the financial dealings and status of political parties and ensuring compliance to this constitutional obligation. It is in line with this constitutional philosophy and the need to regulate and limit political funding that the Companies and Allied Matters Act equally prohibits corporate entities from political donations. The utility and plausibility of this prohibition is not farfetched as such donations and gifts are subject to abuses and susceptible to corruption.

Usually, fund raising ceremonies are organized by political parties to fund campaign extravaganzas. Both individuals and corporate organizations are expected to donate generously. At these ceremonies companies actually donate generously and publicly too. There is no gainsaying the fact that these are illegal donations according to S.38 (2) of the Companies and Allied Matters Act. The section unambiguously prohibits any form of donation or gift to a political party, political association, or for any political purpose. For purposes of clarity the section states thus:

A company shall not have or exercise power either directly or indirectly to make a donation or gift of any of its property or funds to a political party or political association, or for any political purpose; and if any company, in breach of this subsection makes any donations or gift of its property to a political party or association, or for any political purpose, the officers in default and any member who voted for the breach shall be jointly and severally liable to refund to the company the sum or value of the donation or gift and in addition, the company and every such officer or member shall be guilty of an offence and liable to a fine equal to the amount or value of the donation or gift.

It is pertinent to note that the proscription on donations and gifts by companies for political purposes as contained in Section 38(2) of CAMA is precise, all-encompassing and unequivocal, leaving no lacuna or opportunity for circumvention. For instance, the section prohibits companies from making such gifts or donations directly itself or tangentiallythrough a proxy or by representation. This means that a company may still be culpable even if such donation is made through delegation or even a Director or Shareholder. Again, the section creates a legal platform for lifting the veil of incorporation so as to directly hold the officers of the company or the members or both who took the decision to make the gift or donation. To underscore the ultimate appeal of the section, it also creates corporate and individual criminal liability.

Sadly, this provision is observed more in breach by Nigerian companies, especially since the sanctions attached appear to be a cosmetic provision. This is made obvious by the fact that no company has been found culpable under the section in discuss despite the numerous instances of donations to political parties in fragrant breach of the law. This paper recognizes the fact that companies are profit making organisations and it makes good business sense to donate to a party envisaged to be strong enough to win the elections. The understanding behind these gifts need not be written down. There is usually an unmistaken, but unwritten and a non-contradictory pact between the giver and the receiver that such gifts will curdle and court governmental favours to the company when the recipient eventually wins. Otherwise, the question may be asked 
why a profit making organization would give out its shareholders' funds if it was not expecting good returns. In spite of the express prohibition, this provision is largely breached and treated with levity. It thus becomes compelling to ask why this is so and what could be done to make this provision more appealing or easier for companies to comply. Is an outright ban practicable in view of the fact that companies are expected to be good and interactive citizens in the environment within which they operate? Is it absolutely or inescapably necessary to bar companies from political interactions in view of the fact that they will be affected by governmental policies? This paper proposes to attempt answers to these questions in addition to suggesting some mitigating interventions which will most likely satisfy the yearnings of all and bring the law closer to the realities of our time. It is our believe that legislative provisions that are not rooted in the people's beliefs and life style or legislative provisions that are too draconian and far from reality, will not enjoy the people's respect.Even though this research is primarily doctrinal, it enjoys the benefit of diverse approaches including the comparative, analytical and evaluative. For all these, heavy reliance is placed on published materials such as books, journals, documents, reports, papers, communiqués, newspapers, etc. Additional materials are sourced from reliable internet sites.

\section{MONEY IN POLITICAL ARENA}

Democracy the world over appears to be an expensive form of government. The institutionalization of democratic government is not cheap either. It is at this point that funds are needed for campaigns. In Nigeria for instance, the different political parties appear to side-line the purpose of campaigns and rather concentrate and compete with each other on the fanfare. Musicians, comedians and traditional dancers are paid to entertain the audience. Textile factories are paid to produce customized fabrics for each campaign. This aspect usually dominates the campaigns thereby over-shadowing and rendering insignificant, discussions on the parties' ideologies and other important issues. This could be because the parties actually lack ideologies and are not is sue based and so the fanfare is actually a diversionary ploy. However, these diversionary gimmicks cost money. This money must be sourced from different quarters and the companies are easy targets. The way out is for the Independent Electoral Commission to mandate the political parties to drastically reduce the fanfare and expensive extravaganzas and engaged the people more on ideological conversations.

Right from the 1959 elections, individuals and companies funded the electioneering campaigns because the 1958 Nigeria (Electoral Provisions) Order in Council made no provisions for governmental funding. The adverse effects of these gifts and donations by companies to political parties or associations is what prompted the insertion of S.38(2) into CAMA. Companies through such gifts "... bought the consciences of political leaders who will have no choice but to be amenable to their demands" (Ekpo, 2000). Accordingly, it exerted corrupting influences on political office holders resulting in over-valued contracts which were often times not executed. This contributed immensely to official wastefulness and poor management of public resources (Ikhariales, 1999).

It was against this background that the Law Reform Commission concluded thus:

We are all witnesses to the abuses of political donations and gifts in recent political history. We think that no one is in doubt that there is need to plug this loophole for corruption and graft... It is intolerable for the funds and assets of a company in which every shareholder has an interest to be used to foster the interest of a political party in which some do not believe. We therefore recommend that a company should be deprived of the power to make donations or gifts to political parties or as sociations.

Sadly, in spite of the adoption of the Commission's recommendations, this practice is still going on unchecked and done as if it were legal. The prohibition in S.38 (2) is strengthened by S.221 of the 1999 Constitution which bans any other association other than a political party from sponsoring the election of a candidate. The Constitution in section 228 (c) rather authorizes the National Assembly to provide annual grants to the Independent Electoral Commission for disbursement to political parties. Flowing from the provisions of S.221 of the Constitution, a company, not being a political party is prohibited from contributing to the funds of a political party.

Both Ss.38 (2) of CAMA and 221 of the Constitution are highly commendable in view of the mischief they set out to curb. However, this paper is worried by the provisions of section 90 of the Electoral Act 2010which expects a presidential candidate to spend a maximum of $\$ 200 \mathrm{~m}$, a Governorship Candidate to spend $\$ 100 \mathrm{~m}$, Senate, House of Representative and House of Assembly candidates to spend $\$ 40 \mathrm{~m}, \$ 20 \mathrm{~m}$ and $10 \mathrm{~m}$ respectively. These amounts according to section 90 (8) are exclusive of the amounts paid to pick up nomination forms or amounts paid for declaration of interest. The declaration of interest and the picking of nomination forms do not come cheap either, for instance, in the All Progressive Congress (APC), a presidential candidate expresses his interest with 
$\$ 5 \mathrm{~m}$ and picks the nomination form with $\$ 40 \mathrm{~m}$ while a governorship aspirant would pay $\mathrm{N} 2.5 \mathrm{~m}$ for expression of interest form and $\mathrm{N} 20 \mathrm{~m}$ for nomination form making it $\mathrm{N} 22.5 \mathrm{~m}$. The amount is graduated down to the State House of Assembly as contained in the APC 2018 Guidelines for the Nomination of Candidates for Public Office, APC National Secretariat, 2018.Effectively, a presidential candidate in APC is officially expected not to exceed $\$ 127,500,000 \mathrm{~m}$ in his campaigns while a governorship candidates is not expected to exceed $\$ 205,500,000 \mathrm{~m}$ in his campaign expenses.

In an attempt to scale down the high cost of participation in politics, the National Assembly has reviewed the nomination fees downwards and made it uniform for all parties by including it in the bill to amend the electoral Act (Inyang, 2017). The Electoral Act No. 6, 2010 (Amendment) Bill 2017, has made provision for the abolition of arbitrary fixing of nomination fees by politicalparties. It reduces the fee for presidential candidate to N10m, governorship, N5m, Senate $2 \mathrm{~m}$, House of Representatives N1m and House of Assembly, 500,000 . The high cost of participating in politics in Nigeria may discourage people who would have been interested but for financial constraints. The current Nigerian President MohamuduBuhari confessed that he was able to buy the APC nomination form with money borrowed from a bank through the help of a Bank Chairman (Adekunle, 2014).The question may be asked, why he had to go through a Bank Chairman if he was ordinarily qualified for a loan. This takes us back to companies and complicity in funding electioneering. Another issue that this raises is what would have happened to the loan if the recipient of such an arranged loan had not been successful. How would the loan have been paid back to the bank? This probably would have become another case of a non performing loan. Invariably, this is corporate sponsorship of a political candidate taking another coloration.

As interesting and as well intentioned as these prohibitions may be; it is doubtful if the Federal Government of Nigeria can comfortably fund the current number as more political parties have recently been registered. This is a continuous exercise we have well over 90 political parties and it may be impossible to fund them through appropriation by the National Assembly under S.228 of the Constitution. This is even more disturbing given the current economic recession in Nigeria. It must be emphasized here that the amounts expended byObasanjo, a former President of Nigeria for 8 years and a huge beneficiary of corporate sponsorship for his elections is more than would have been needed to fight a successful war" (Obasanjo, 2003). This statement must be taken seriously since it was made by a retired General in the Nigerian army. The enormity of the situation also led an erstwhile Chairman of the Independent Electoral Commission (INEC), Iwu to call for the taxing of such donations so as to discourage the practice. Jonathan, a former Nigerian President is widely reported to have raised over $\mathrm{N} 21 \mathrm{~b}$ from both corporate organizations and others for this 2015 elections. Taxing may generate funds to the federal Government, but it will not discourage the practice. Rather, it will encourage such donations to be made discretely. What can deter is enforcement of the sanctions attached to the law (Adetula, 2015).

However, S. 90 of the Electoral Act 2010 as amended in 2011 gives INEC the power to limit donations to political parties. Accordingly, political parties are not expected to keep anonymous monetary contributions or gifts.In addition, S.93 (2) mandates political parties to "keep an accounts and as set book" where all contributions received in excess of $\$ 1 \mathrm{~m}$ are recorded with names and addresses of donors. This is to assist the political parties in compiling their report on this to INEC after the announcement of election results. Unfortunately, there is no punishment in the section for none compliance.

\section{THE ENFORCEMENT QUAGMIRE}

In spite of the clear prohibition in S. 38(2) CAMA, gifts to political parties, politicians and political meddling by companies in Nigeria has continued unabated and may be said to be encouraged by those who ought ordinarily to be the custodians of the law in Nigeria. It can be asserted here without fear of contradiction that since the coming into effect of CAMA, all Nigerian Presidents and their political parties have benefited from corporate gifts for their campaigns. This is why this law is largely ignored by the Attorney-General who naturally is an appointee of the President. In 2000, Williams, berated the AttorneyGeneral (AG) of Nigeria for failing to prosecute Julius Berger for donating to the People's Democratic Party which was the ruling party in Nigeria then. He expressed the fact that every law should be law. The frustration in getting an unwilling AG to prosecute a criminal was witnessed by Nigerians in Gani Fawehinmi v. Akilu. This frustration in the lack of enforcement of S.38(2), led the petitioner in Obasango v. Yusufto seek the annulment of the election of Obasanjo on the grounds that he had a public fund raising ceremony for his elections where corporate organizations donated. Unfortunately, even though the court held such gifts to be illegal, it dis missed the suit for want of jurisdiction.

Also, a breach of S. 38(2) is a classic case for a derivation action by a shareholder under S. 300(9) of CAMA. However, despite the frequency of breach, there is dearth in such reported cases. The question that may be asked here is why this is so? This paper posits that the answer to this may be multi-faceted. First, it may be that those 
responsible for publicizing the law have failed to do so. Second, the shareholders see nothing wrong in supporting a political cause that may be beneficial to their company in the long-run. Thus, if a law is discountenanced by its custodians and the citizenry, it is time to revisit the law in order to enable it attend its desired objectives as well as enjoy the respect of all.

Moreover, our laws should be dynamic and evolve with changing times in a globalised world. Sadly, the outright prohibition contained in S. 38(2) is reproduced as S. 37(2) in the bill to amend and replace CAMA which is currently pending at the Nigerian National Assembly. The danger in this is that, even if CAMA is eventually replaced this blanket prohibition, which is no longer trendy in other jurisdictions, it will still be a part of the Nigerian Company Law, even when it serves no practical purpose without enforcement.

\section{PERSPECTIVE FROM INDIA AND THE UNITED KINGDOM}

The problem of corporate intrusion into the political arena especially via campaigns funding is by no means a Nigerian phenomenon. These problems occur in other jurisdictions also, but the difference lies in the way this issue is treated in each jurisdiction.

\subsection{Corporate Donations in India}

In India, donations by companies to political parties and donations for political purposes have increased in recent times. It has been reported that such donations have risen to as high as $151 \%$ between 2014 and 2015 (Ghadha, 2015). Within this period also, corporate organisations have been reported to contribute $90 \%$ of the total donations to political parties with the Bhartic group leading by donating a third of the funds needed by BharatiyaJanata Party (B.J.P.). This increase may be because an outright prohibition against political donations by corporate had been abolished with the exception of government companies and companies which have not existed for up to three years.

Now by S. 182(1) of the 2013 Indian Companies Act, companies apart from the two groups earlier mentioned, can donate for political purposes. Such contributions are not expected to exceed $71 / 2 \%$ of the company's average net profit in the past three years. This must also appear in the company's annual accounts. This has to be done with the authorization of the company's board of directors through a resolution.

It is interesting to note that donations for genuine charitable purposes can be made by the board of directors. However, by S. 181 of the Indian Companies Act 2013, if the amount to be donated exceed $5 \%$ authorisation of the general meeting before the gift can be made.Political donations by companies are expected to be reflected in the company's profit and loss account for the period. It is intriguing to note that while political donations need the boards' approval, that for charitable purposes which exceed $5 \%$ of the company's net profit needs the approval of the shareholders. Could this have been dictated by the need to take expeditions decisions on the issue? This paper submits that the shareholders interest is best served if both are made to receive shareholders' authorization. Irrespective of the above observation, the Indian position is far better than the blanket ban in Nigeria. The Indian Act recognizes the need for companies to interact with their communities, since they could be adversely affected if they remain aloof and a bad government is elected into power. A breach of this law attracts punishment for both the company and its officers. Upon breach, the company may be made to pay a fine which may be five times the amount contributed, while its officers are liable to the same fine and in addition to an imprisonment for up to six months as contained in S. 182 of the Indian Companies Act.This law is more likely to be obeyed because it creates leverage for compliance unlike S. 38(2) of CAMA.

4.2 Political Donations under the English Companies Act 2006

Under the English Companies Act 2006 elaborate provisions are made on this issue. Part 14, comprising of 17 sections is dedicated to it. Definitions of the phrases, political donations, political parties, political organisations and political expenditure are clearly given sections 363, 364 and 365. These definitions are absent in CAMA. One therefore has to resort to some other legislation for the meanings of these phrases in Nigeria. The English Act demonstrates a clear and serious intention to place things in their proper perspectives devoid of ambiguities.

By Ss. 367 and 368, an ordinary resolution of members is all that is required to authorize the directors to make such donations. Also, S. 368 expects the authorisation to last for four years unless the articles or the directors determine that it should be for a shorter period. The authorizing resolution must set a monetary limit. A breach of these provisions renders the directors jointly and severally liable to refund the amount in issue with interest to the company. In addition, they are bound to compensate the company for any loss or damage incurred as a result of the breach. Interestingly, these provisions may be enforced by a group of members holding not less than $5 \%$ of the companies share value or not less than 50 of its members or $5 \%$ of members of the company, if the company is not limited by shares. This is of course limited to the conditions contained in S. 371 of the Act. It should be stressed here that this paper favors authorization to make political donations through a simple resolution of members as contained in S. 367 of the English Act as opposed to a situation where the board 
authorizes itself as contained in S. 182 of the Indian Act. In the latter case, the board may whittle away shareholders' funds to further the political ambition of their members.

\section{CONCLUSION AND RECOMMENDATIONS}

This paper set out to assess the effectiveness or otherwise of the prohibition in S. 38(2) of CAMA, expose the level of compliance with a view to proposing some mitigating parameters which may most likely improve the compliance level. The paper considered the historical antecedents of this prohibition and noted the mischief it was meant to curb, it also noted that this mischief still exist in present day Nigeria. The paper realized that there tend to be general apathy towards enforcement by both the shareholders and the Attorney-General. The paper therefore concluded that this is an indication of the unpopularity of the law. It surmises that the practice of corporate donating for political purposes have become so entrenched that it has become normative in Nigeria.

This however is encouraged by the ignorance of shareholders as those who ought to enlighten them have failed to do so for obvious reasons. This paper therefore concludes that the frequency, blatancy and even tacit approval of this practice does not derogate the fact that this practice is offensive to the spirit behind the enactment is S. 38(2) of CAMA and therefore, something ought to be done to encourage compliance.

This article also took a cursory look at the manner of electioneering campaigns in Nigeria and decried the lack of ideologies and is sue based campaigns. It observed that the diversionary fanfare campaigns are more expensive and therefore should be discouraged. This will reduce the cost of campaigns and also the pressure on companies to donate and in addition enable more descent people with lean purses to aspire to political positions. A perusal of relevant provisions of the Electoral Act and the APC Guidelines for Nomination of Candidates revealed humongous amounts the candidates are expected to spend during their campaigns. This paper therefore concludes that this will rather encourage a breach of the prohibition in S. 38(2) of CAMA and neither can Nigeria in its present economic quagmire adequately fund the present number of political parties in the country.

Unfortunately, while CAMA's sanctions in S. 38(2) may be said to be mere paper tigers for lack of enforcement, the provisions in S. 93 of the Electoral Act can be said to be a toothless bull-dog for lack of punishment for breach. S. 93 would have greatly assisted CAMA if it provides punishment for its breach. The provision on corporate donations for political activities in India and the United Kingdom was examined. It was discovered that these two jurisdictions have abandoned the outright proscription in favour of provisions which rather regulate such donations. This is a better and more practicable approach than the ban in S. 38(2) of CAMA.

It is important to re-emphas is here that the new Act being envisaged to replace CAMA will serve no useful purpose in the modernization of CAMA on this issue as the provisions in S. 38(2) has simply been repeated as $\mathrm{S}$. 37(2). Invariably, when and if the law comes into effect, Nigeria will continue to lag behind the rest of the world on this issue.

Flowing from the above, the following recommendations are considered apposite.To nib this problem in the bud, the Electoral Act should have new provisions which will reduce the influence of money in electioneering campaigns. The parties should be made to base their campaigns on relevant issues and not on side attractions which cost money. There is need therefore to amend S. 90 of the current Electoral Act so as to reduce the maximum monetary expectations of candidates for campaigns. This in effect will reduce the desperation and the tendency to pressurize campaigns for as sistance.

S. 38(2) of CAMA is in dire need of amendment. It should be amended so that companies apart from government owned companies can donate out of their net profit. The Act needs to specify the percentage of the net profit for the year which cannot be exceeded. The approval to do so should be given to the board by the members. Such donations should be well recorded and should reflect in the company's annual accounts. The record should indicate the political party or the political cause to which the money is donated. There should be robust enforcement framework to deter breach.

The Nigerian Corporate Affairs Commission should be properly funded and staffed so as to perform its regulatory functions in companies effectively. The Electoral Act should be amended so as to include provisions which disqualify candidates who receive gifts from corporations in breach of the amended S. 38(2). Enforcement of the civil and criminal sanctions attached to the provisions in CAMA should be taken seriously.

\section{REFERENCES}

[1] Adekunle A. (2014). "Buhari took Bank loan to purchase APC nomination form" Vanguard Newspaper, (online ed.), http://vanguardngr.com.news. Accessed $9^{\text {th }}$ April 2017.

[2] APC 2014 Guidelines for the Nomination of Candidates for Public Office, APC National Secretariat, 2014, pp, 4-5.

[3] "Big Corporate Donors to the B.J.P. Congress in FY14/16/feb.2015, http://Rediff.com $>>$ Business $>$, accessed $10^{\text {th }}$ March 2018. 
[4] Inyang B. (2017).“2019 Presidential Nomination Forms to Cost $\$ 10 m$ ”, Daily Post, (Online ed. 3 April 2017), http://dailypost.ngaccessed, $5^{\text {th }}$ April 2018.

[5] Law Reform Commission, "Report on the Reform of Nigerian Company Law, [1988] (1) 60, para 138.

[6] IkharialeM.A. (1991). "Corporate Political Spending under the Companies and Allied Matters Decree: An Appraisal" 2 Justice, 23 cited in Ekpo, op. cit., 37.

[7] EkpoM.E. (2000). "Corporate Gifts for Political Purposes: An Analytical Exposition of Section 38(2) of the Companies \&Allied Matters Act, 1990. Unimaid Journal of Public Law, 39.

[8] Niyi F. (2016). "INEC Releases New List of Registered Political Parties", http://informationng.com>news, 2016/10>, access, $9^{\text {th }}$ April 2018.

[9] Obasanjo O. (2003). In an address on Electoral Reform in an INEC-Civil Society Forum/Seminar, Abuja, Nigeria, 27 Nov. 2003 For more details, see Nig-Electoral Journal, Vol. 3 at

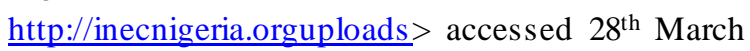
2017.

[10] OrjiR.O. (2014)."Political Funding in Nigeria: A Case of Peoples Democratic Party". 2(11) Arabian Journal of Business \& Management Rev. (Nigerian Chapter) https://arabianjbmr.com accessed $21^{\text {st }}$ October, 2018.

[11] GhadhaS. (nd). Political Donations up $151 \%$ this year, BJP tops list", Retrieved from http://m.hindustrantimes.comupdated Dec. 8, 2015, accessed $13^{\text {th }}$ October, 2018.

[12] The Guardian Newspaper, (June 22000 ).

[13] The Hindu, " $90 \%$ donations to Political Parties from Corporates", 25 Dec. 2014, http://thehindu@thehindu.comupdated $4^{\text {th }}$ Feb., 2015, accessed 15 th April 2017.

[14] Adetula V.A. (2015). "God fathers, money, Politics and Electoral Violence in Nigeria, Focinus on 2015". A Conference paper, INEC, Nig. $<$ http:inecnigeria.org>uploads $>2015$ accessed, $19^{\text {th }}$ October, 2018.

[15] Thomas Z. (2017). “US Elections 2016: who's funding Trump, Sanders \&The Rest?" <bbc.com> (March 17 2017) accessed 24 ${ }^{\text {th }}$ September, 2018.

[16] [1987] 4 NWLR (pt. 67) 797.

[17] [2005] Vol. 20 WRN. 1 